\title{
GENERATION AND MANAGEMENT OF DISASTER WASTE
}

\author{
HARUO HAYASHI ${ }^{\mathrm{i})}$ and TAKESHI KATSUMI ${ }^{\mathrm{ii}}$
}

\begin{abstract}
The 1995 Hyogoken-Nambu earthquake of January 17, 1995 resulted in a devastating damages to the highly developed urbanized region of Kansai, and created a total of 20,000 Gg (20,000,000 ton) of debris. Debris clearance in two years became an urgent and difficult emergency management issue for the disaster managers in Kobe city and Hyogo prefecture. The status of debris clearance was reviewed for each of the demolition operation phase, transportation, crushing and separation at a temporary storage location, disposal at final landfill site phases in terms of problems and state of progress. In practice, most of the debris may be either disposed of at landfill sites or reused as materials for construction. Therefore the debris clearance operation should focus on the geotechnical engineering approach as an important post-disaster issue to control the quality of the incoming flow of potential soil materials. The importance of an emergency management perspective in this geotechnical approach which takes into account the different criteria related to the operation execution is proposed.
\end{abstract}

Key words: earthquake damage, environmental impact, geographic information system, land reclamation, wastes (IGC: B12/B4)

\section{INTRODUCTION}

The 1995 Hyogoken-Nambu earthquake of January 17,1995 , a magnitude of 7.2 (Richter scale), was the first major earthquake which hit a highly developed urban region in Japan since the 1923 Kanto earthquake. This earthquake resulted in devastating damage of more than 6,300 deaths and a total of about 17 trillion yen (200 billion US dollars) direct physical loss from damage in the Kansai area, mainly in Kobe city of Hyogo prefecture. About 200,000 public and private buildings and individual houses collapsed, and many road and railway bridges have also collapsed. Accordingly, about $20,000 \mathrm{Gg}$ of debris was generated suddenly due to this earthquake, as shown in Table 1 , which is equivalent to about $1 / 4$ of the

Table 1. Comparison between the disaster waste generation due to the earthquake and normal waste generation

\begin{tabular}{l|r}
\hline $\begin{array}{l}\text { Disaster waste due to the } 1995 \text { Hyogoken-Nambu } \\
\text { earthquake }\end{array}$ & $20000 \mathrm{Gg}$ \\
\hline Municipal waste in Kobe city per year & $600-700 \mathrm{Gg}$ \\
\hline Municipal waste in Hyogo Prefecture per year & $2300 \mathrm{Gg}$ \\
\hline Construction waste in Kansai area in fiscal year 1993 & $14000 \mathrm{Gg}$ \\
\hline Construction waste in Japan in fiscal year 1993 & $76000 \mathrm{Gg}$ \\
\hline
\end{tabular}

$1 \mathrm{Gg}=1000$ ton volume of total construction waste generated in Japan in fiscal year 1993, or equivalent to about $150 \%$ of the construction wastes generated within the Kansai region in that year. Debris clearance became one of the most urgent and difficult emergency management issues for disaster managers in both Kobe city and Hyogo prefecture as the indispensable basis for the recovery process. The national government promised that $95 \%$ of the expenses required for clearing debris generated from private buildings would be subsidized, and the government also set a time limit by March of 1996 when all the debris would be cleared from the impacted area, and the entire debris clearance operation would be completed by March, 1997. Actually, most of the debris may be either disposed of at landfill sites or reused as construction materials such as coastal reclamation. Debris clearance operation should therefore be focused from the geotechnical engineering approach as an important post-disaster issue related to the control of the quality of the incoming flow of possible soil material, as well as the geotechnical aspects of normal waste management (Kamon, 1994).

Debris clearance operations were begun immediately after the earthquake as shown in Table 2 . In the immediate response phase for the first several days after the earthquake, debris was cleared for search and rescue of disaster victims by both local residents and emergency officers such as fire-fighters, policemen, and the self-

i) Associate Professor, Disaster Prevention Research Institute, Kyoto University, Gokasho, Uji, Kyoto 611.

ii) Research Associate, ditto. Manuscript was received for review on August 17, 1995.

Written discussions on this paper should be submitted before August 1, 1996, to the Japanese Geotechnical Society, Sugayama Bldg. 4F, Kanda Awaji-cho 2-23, Chiyoda-ku, Tokyo 101, Japan. Upon request the closing date may be extended one month. 
Table 2. Disaster waste management related to each phase after the disaster

\begin{tabular}{c|l|l}
\hline No. & \multicolumn{1}{|c|}{ Phase } & \multicolumn{1}{c}{ Required content } \\
\hline 1 & $\begin{array}{l}\text { Immediate } \\
\text { response } \\
\text { phase }\end{array}$ & $\begin{array}{l}\text { Rescue, prevention of secondary disaster, } \\
\text { and security of life }\end{array}$ \\
\hline 2 & $\begin{array}{l}\text { Recovery } \\
\text { phase }\end{array}$ & Security of road network \\
\hline 3 & $\begin{array}{l}\text { Restoration } \\
\text { phase }\end{array}$ & $\begin{array}{l}\text { The basis for restoration process. } \\
\text { Preservation of property }\end{array}$ \\
\hline
\end{tabular}

defense forces everywhere in the impacted area. In this recovery operation phase, some of the collapsed buildings and highway bridges were demolished and removed by the local and national government to secure the trunk road networks for recovery operations. In the restoration phase, debris clearance generated by the individual uses and private buildings was begun and it became a serious issue to coordinate the entire process from the application for debris clearance to the processing at the final disposal site.

The debris clearance operations for all of these phases followed the regular industrial waste processing scheme used in Japan as a model for emergency operations. In this paper, the status of waste management after the 1995 Hyogoken-Nambu earthquake is reviewed in general and debris clearance in particular, focusing on operations in Kobe city where the most severe damage took place. In addition, the necessity for an emergency management perspective for debris clearance is proposed. Initially a brief summary of the regular waste management scheme used in Japan is presented.

\section{WASTE MANAGEMENT SYSTEM IN JAPAN}

\section{Municipal Wastes and Industrial Wastes}

The Ministry of Health and Welfare regulates waste management in Japan based on the "Waste Disposal and Public Cleaning Law" enacted in 1971. According to this law, waste may include solid and bulky waste, cinders, sludge, night soil, waste oil, waste acid, waste alkaline, and dead animals, but may exclude radioactive waste and surplus soil. With regard to the responsibility for waste management, waste may be classified into two subclasses: industrial and municipal wastes. Industrial waste is defined by the law as the waste generated from some business activities. It is the responsibility of the beneficiary of business activities to treat and dispose of industrial waste at their own expense. Municipal waste is considered to be that generated by the daily activities of the citizens and it is the responsibility of the local government to treat and dispose of it. For both industrial and municipal waste, special treatments have been required for the processing of explosive, toxic, or infectious materials which may be hazardous for health and environmental such as PCB and asbestos.

According to the Ministry of Health and Welfare, the waste generated by natural disasters such as earthquake may be called "disaster waste," which includes (1) night soil, (2) residential solid waste, and (3) debris. With regard to debris clearance, the national government promised a subsidy for privately owned buildings and facilities to speed up the clearance. It would be subsidized to the extent of $97.5 \%$ of all expenses required for clearing debris generated by individual houses and those private buildings owned by small businesses. The debris clearance of those private buildings owned by big businesses with the exemption for the expenses required for demolition would also be subsidized. In summary the distinction between industrial and municipal waste became blurred as to the disaster debris disposal and it became the responsibility of local government to process all kinds of disaster waste. The waste management capability of the local government therefore became an issue.

\section{Basic Types of Waste Disposal Sites}

It has always been a severe problem to secure ample waste disposal space in Japan. The reason for this is partly because of the scarcity of available inland areas for final disposal. As a consequence, coastal reclamation with waste materials has been a common practice in many urban areas in order to obtain adequate disposal space. At the final disposal site, there are three different types of systems based on the degree of control of leachate from the reclaimed waste: (1) least controlled landfill sites for safe and stable waste, (2) controlled landfill sites for safe but unstable waste, and (3) strictly controlled landfill sites for hazardous waste. As shown in Table 3, the debris generated from an earthquake is basically construction waste in general. Construction waste amounts to about $20 \%$ of all industrial waste, and includes (1) concrete and brick, (2) plastic, (3) glass and ceramic, (4) metal, (5) rubber, (6) sludge, (7) wood, and (8) oil waste. The first five categories can be disposed of at "least controlled" landfill sites because they are safe and stable materials for reclamation.

As a common practice, each municipality has been responsible for securing disposal sites for those wastes generated within their jurisdiction. In the Kansai area,

Table 3. Generation of disaster waste and the recycling plan of Hyogo prefectural government

\begin{tabular}{l|l|l}
\hline \multicolumn{1}{c|}{$\begin{array}{c}\text { Waste } \\
\text { generation }\end{array}$} & $\begin{array}{l}\text { Type and amount of } \\
\text { recycling material }\end{array}$ & \multicolumn{1}{c}{ Purpose } \\
\hline $\begin{array}{l}\text { Noncombustible } \\
\text { waste } \\
(16200 \mathrm{Gg})\end{array}$ & $\begin{array}{l}\text { Concrete } \\
(12500 \mathrm{Gg})\end{array}$ & $\begin{array}{l}\text { Reclamation: } 11000 \mathrm{Gg} \\
\text { Construction: } 1500 \mathrm{Gg}\end{array}$ \\
\cline { 2 - 3 } & $\begin{array}{l}\text { Metal } \\
(510 \mathrm{Gg})\end{array}$ & Steel manufacture \\
\hline $\begin{array}{l}\text { Combustible } \\
\text { waste } \\
(3800 \mathrm{Gg})\end{array}$ & $\begin{array}{l}\text { Wood } \\
(80 \mathrm{Gg})\end{array}$ & Pulpwood, Fuel, Fertilizer \\
\hline Total: $20000 \mathrm{Gg}$ & $13090 \mathrm{Gg}(65.5 \%)$ & \\
\hline
\end{tabular}

$1 \mathrm{Gg}=1000$ ton 
securing waste disposal sites within their jurisdiction has been so difficult for many municipalities that a large landfill site, named "Phoenix Center," has been established in the coastal area of Hanshin as the common final disposal site for the Kansai region.

\section{Basic Rules for the Waste Management}

Since there is always an upper limit for waste disposal space, there are three basic rules for the waste management. The first rule is the minimization of waste generation. There has been practiced in many ways; (1) size reduction by milling and shredding, (2) incineration, (3) dehydration, and (4) desiccation. The second rule is the practice of making the wastes sanitary. Incineration has been the most popular practice in this respect in Japan. The third rule is the promotion of recycling. The debris may be either disposed of at a coastal reclamation landfill site as soil material or reused as material for construction. In order to practice these three rules, it is important to coordinate all the tasks required for waste management in the following stages: (1) demolition, (2) transportation, (3) intermediate treatment, and (4) final disposal at landfill site.

\section{GENERATION, MANAGEMENT AND RELATED PROBLEMS OF DISASTER WASTE}

Three types of wastes were generated due to the 1995 Hyogoken-Nambu earthquake, including night soil, residential solid waste, and debris. The generation as well as the management of the disaster waste depends on the phase after the earthquake. The Hyogo prefectural government estimated the volume of the debris generated due to the earthquake to be about $20,000 \mathrm{Gg}$ as their third estimate after careful examination and discussion. Table 3 and Fig. 1 indicate the types of debris generated and the management plan for each type of debris. The

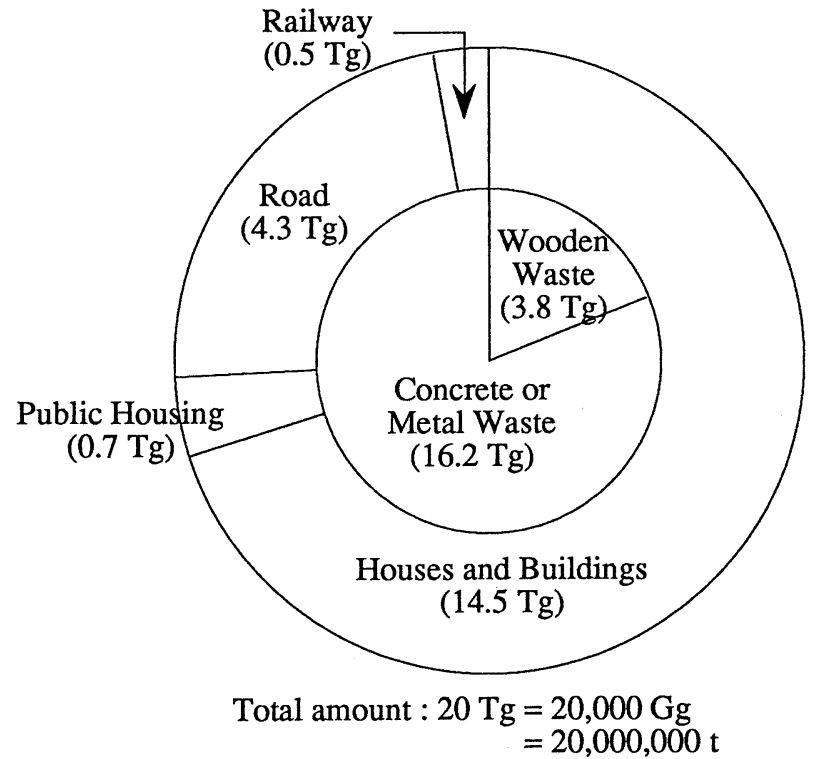

Fig. 1. Debris generation due to the earthquake estimated by the Hyogo prefectural government

basic strategy was to execute separation or incineration at temporary storage locations in order for both size reduction and recycling of the waste materials to be implemented. Figure 2 shows the management flow adopted by the Kobe municipal government following the guidance from Hyogo prefecture. The present and anticipated influence of the disaster waste management due to the earthquake are summarized in Fig. 3.

\section{Waste Management Related to Night Soil and Garbage Collection}

The processing of excrement was the first issue of the disaster waste management program, because the water supply system and sewage system were heavily damaged

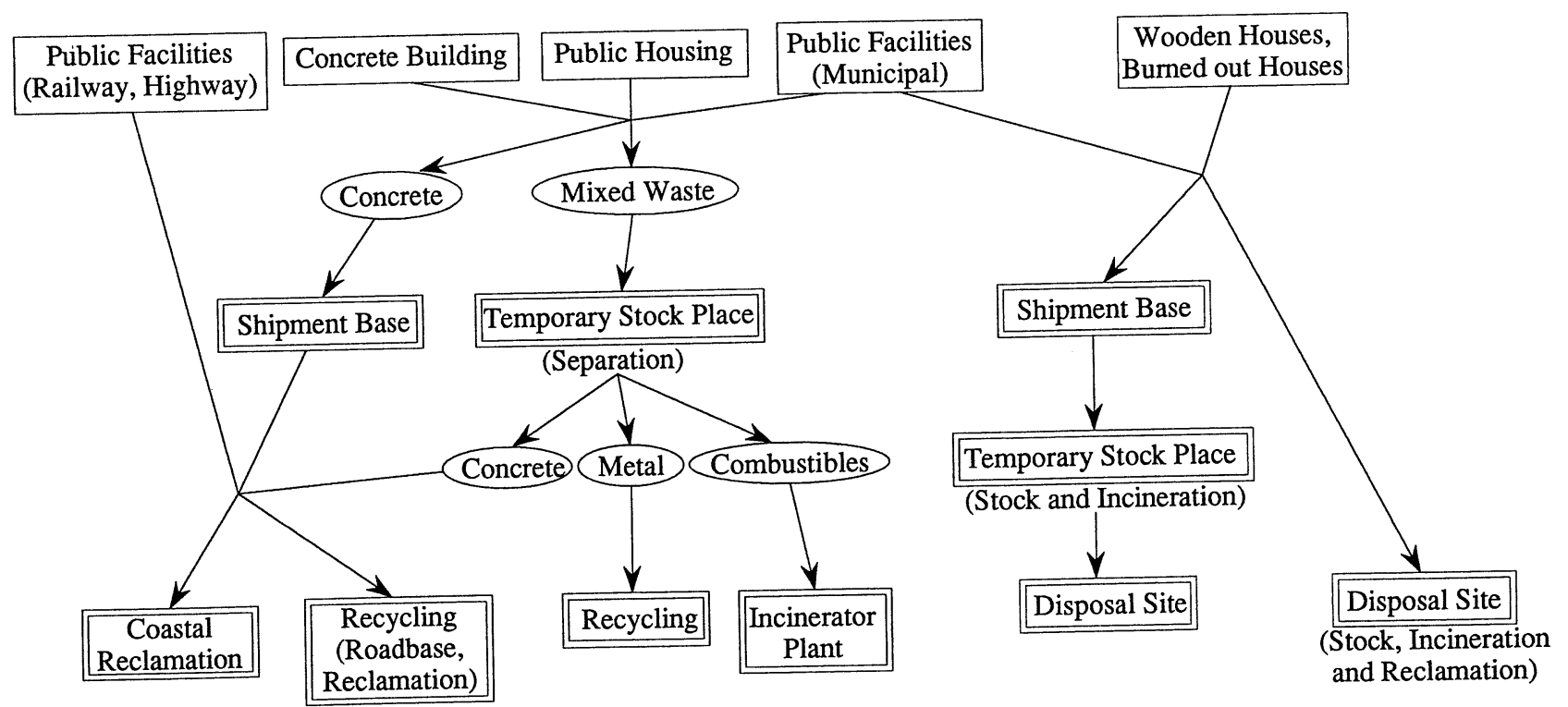

Fig. 2. Management plan for disaster waste by Kobe municipal government 


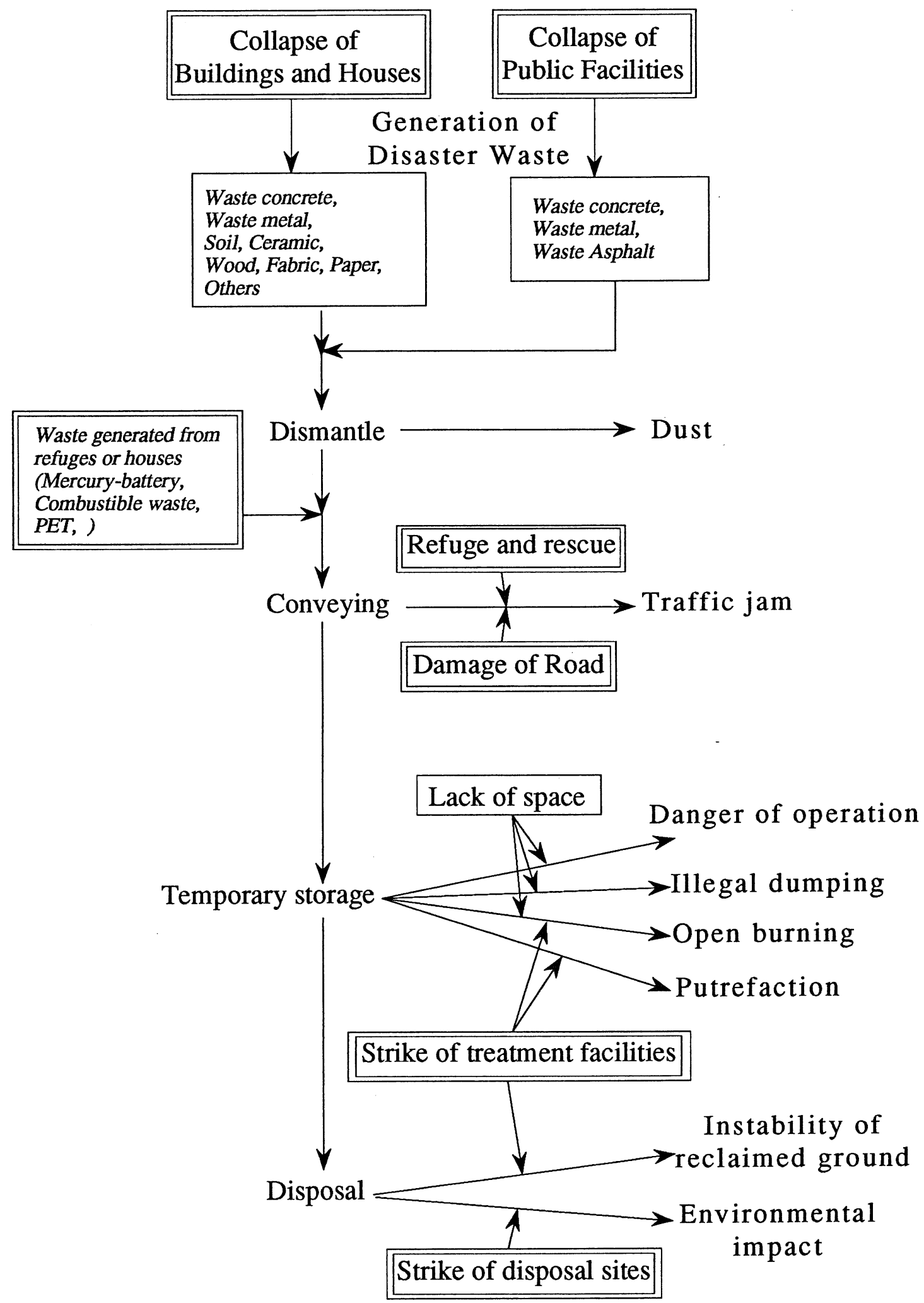

Fig. 3. Outline of waste management and its impact

by the earthquake. A maximum of 320,000 refugees were located in 1,150 shelters. A total of 3,900 temporary toilet systems were installed at the shelters within 10 days after the earthquake (Kasuya and Iwasa, 1995).

The stockpiling of residential solid waste on streets was another distinctive disaster waste management prob- lem. Many food and drink containers and bulky waste were generated soon after the earthquake. The garbage collection system was interrupted for the first four or five days after the quake. As a result, this waste was stockpiled on the streets. When these wastes were removed to temporary storage locations, garbage was stockpiled in a 


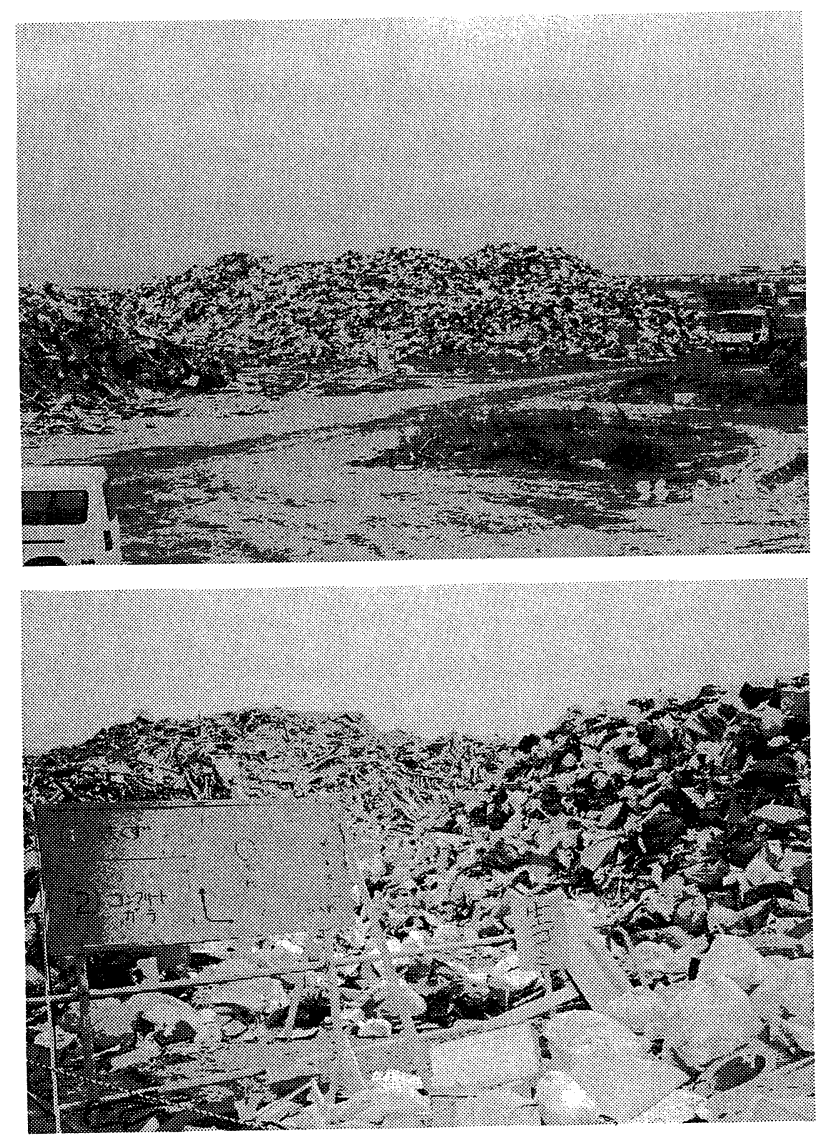

Photo. 1. Stockpile of household waste including garbage at a temporary storage location in Nishinomiya city different from the rest of the wastes. The pile of garbage has however remained there for many days even after the regular garbage collection and combustion service was restored, as shown in Photo. 1 (JGS, 1996).

Another big concern was the environmental impact due to rough treatment of damaged or abandoned electric appliances containing hazardous chemicals, such as refrigerators containing fluorocarbons. As a result of a great effort by the local government in cooperation with volunteer groups, about 5,000 abandoned refrigerators were collected by April and the fluorocarbon was extracted from them safely for the environmental protection (Kobayashi, 1995).

\section{Demolition of Collapsed Structures}

The major issue of disaster waste was the management of collapsed houses and buildings and other public facilities. The total volume of the demolition waste was estimated to exceed $20,000 \mathrm{Gg}$. The collapse of wooden houses was remarkable, particularly in the belt area of JMS 7 in Kobe city (Wards of Chuo, Nada and Higashinada), Ashiya city and Nishinomiya city. 120,000 individual houses have been requested to be dismantled in this area, as shown in Table 4. The debris from such wooden houses includes not only the waste timber and concrete blocks, but also soils, clothes, furniture, electric appliances and so on. In many cases they were mixed up with each other. For collapsed buildings and public facilities, the debris generated was mainly concrete and scrap steel. On-site separation of the debris may therefore be easier than for individual ordinary houses. The highway

Table 4. The number of houses destroyed and progress of dismantling

\begin{tabular}{|c|c|c|c|c|c|c|c|}
\hline \multirow[b]{2}{*}{ City } & \multirow{2}{*}{$\begin{array}{l}\text { Number of } \\
\text { households } \\
\text { (A) }\end{array}$} & \multirow{2}{*}{$\begin{array}{l}\text { Number of } \\
\text { houses } \\
\text { completely } \\
\text { destroyed } \\
\text { (B) }\end{array}$} & \multirow{2}{*}{$\begin{array}{l}\text { Number } \\
\text { of houses } \\
\text { partially } \\
\text { destroyed } \\
\text { (C) }\end{array}$} & \multirow{2}{*}{$\begin{array}{l}\text { Destruction } \\
\text { ratio }(\%) \\
\text { (D) }\end{array}$} & \multirow{2}{*}{$\begin{array}{l}\text { Number of } \\
\text { houses } \\
\text { expected to } \\
\text { be } \\
\text { dismantled }\end{array}$} & \multicolumn{2}{|c|}{$\begin{array}{c}\text { Dismantle } \\
\text { progress ratio }(\%)\end{array}$} \\
\hline & & & & & & $\begin{array}{l}\text { End of } \\
\text { March }\end{array}$ & $\begin{array}{l}\text { End of } \\
\text { May }\end{array}$ \\
\hline $\begin{array}{l}\text { Kobe city } \\
\text { Higashinada ward } \\
\text { Nada ward } \\
\text { Chuo ward } \\
\text { Hyogo ward } \\
\text { Nagata ward } \\
\text { Suma ward } \\
\text { Tarumi ward }\end{array}$ & $\begin{array}{r}579259 \\
77219 \\
55361 \\
52283 \\
53334 \\
53306 \\
66293 \\
87313\end{array}$ & $\begin{array}{r}54949 \\
11171 \\
11693 \\
4947 \\
8374 \\
12525 \\
6042 \\
90\end{array}$ & $\begin{array}{r}31783 \\
3098 \\
3559 \\
3420 \\
4422 \\
4994 \\
4093 \\
5520\end{array}$ & $\begin{array}{r}12.2 \\
16.5 \\
24.3 \\
12.7 \\
19.8 \\
28.2 \\
12.2 \\
3.3 \\
\end{array}$ & 73817 & 25.3 & 52.3 \\
\hline Nishinomiya city & 162246 & 17716 & 13474 & 15.1 & 17041 & 25.6 & 69.4 \\
\hline Ashiya city & 33643 & 2543 & 1519 & 9.8 & 5250 & 30.4 & 60.1 \\
\hline Amagasaki city & 192340 & 603 & 3966 & 1.3 & 5192 & 1.5 & 26.5 \\
\hline Takarazuka city & 71558 & 1339 & 3718 & 4.5 & 4787 & 10.9 & 71.4 \\
\hline Akashi city & - & - & - & - & 2634 & 10.8 & 44.0 \\
\hline Itami city & 65690 & 354 & 623 & 1.0 & 2613 & 33.2 & 55.0 \\
\hline Hokudan town & 3682 & 1341 & 550 & 38.2 & 2150 & 55.7 & 99.5 \\
\hline Total & - & - & - & - & 122037 & 26.7 & 57.7 \\
\hline
\end{tabular}

Date are based on the statistics of Hyogo prefectural government and Kobe municipal government.

${ }^{*} \mathrm{D}=(\mathrm{B}+0.5 \times \mathrm{C}) / \mathrm{A} \times 100(\%)$ 
bridges of the Hanshin Expressway which failed on Route No. 43 consecutively for about $600 \mathrm{~m}$ were demolished and removed for 10 days starting from January 20. A total of $46,276 \mathrm{Mg}$ of demolition waste was consequently discharged (Irie and Mori, 1995). Some of the concrete lumps were temporarily stockpiled in the area of the waste disposal site (Phoenix Center) to be reused as a road base material.

\section{Progress and Problems of Demolishing Collapsed Struc- tures}

Demolition of public facilities and individual houses was carried out on a contract work basis by general contractors or other construction companies. Table 4 indicates impressive figures as to the progress and speed of the demolition operations; $27 \%$ of the total operations were been completed in the first two months and 58\% was accomplished in the first four months. There has been a trade-off between the speed and the quality of perations. In many cases, demolition workers did their job just mechanically so that little on-site separation of waste was done. This resulted in a low quality of waste which could not be disposed of at "least controlled" disposal sites, and it also made size reduction at intermediate processing locations more difficult and costly.

Environmental concerns for dust distribution from demolition operations attracted much attention. It was recommended that the target buildings be covered and watered down to prevent dust distribution. Because some dismantled buildings contained asbestos, the Environmental Agency of Japan carried out a field investigation on asbestos distribution in the air. The results as indicated by Table 5 were that the environmental impact due to demolition of the collapsed buildings may be negligible on an average, however, the asbestos distribution tended to be higher at locations closed to the demolition operations than the average.

Some tools and devices were introduced for the demolion operations at large building and bridge structures. Photograph 2 shows the demolition of collapsed road bridges of Hanshin Expressway which collapsed on Route No. 43. A mound of soil was placed under the
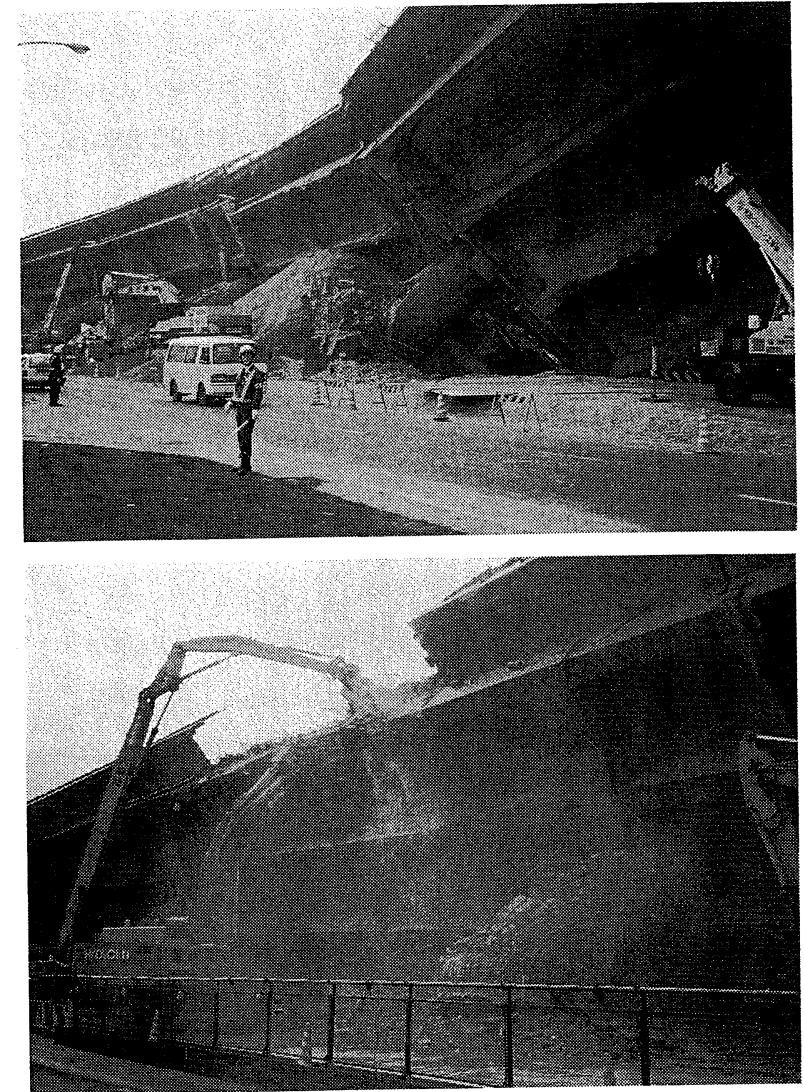

Photo. 2. Demolition of collapsed road bridges (Photos by J. Okada, Nakabori Soil Corner Co.)

elevated structures for the protection of workers, vehicles and surface roads from falling objects such as crushed concrete pieces. A crushing equipment system named "Nibbler" was used for the demolition of beams.

\section{Transportation of Debris}

Debris was transported either to temporary storage locations or final disposal sites. Because of the poor serviceability of the road network due to severe damage to two Hanshin expressways cutting through the impacted area, many debris transporting trucks became an addi-

Table 5. Results of measurement of asbestos in the air

\begin{tabular}{|c|c|c|c|c|}
\hline Measurement point & Date & Min.-Max. value & Medium & Mean \\
\hline Ordinary area in Hanshin & Feb. 6-12, 1995 & ND-4.9 f/l & $1.0 \mathrm{f} / 1$ & $1.0 \mathrm{f} / 1$ \\
\hline Ordinary area in Hanshin & Mar. 9-16, 1995 & $0.3-6.0 \mathrm{f} / 1$ & $1.0 \mathrm{f} / 1$ & $1.2 \mathrm{f} / 1$ \\
\hline Ordinary area in Hanshin & Apr. 24-28, 1995 & $0.2-2.1 \mathrm{f} / 1$ & $1.0 \mathrm{f} / 1$ & $0.9 \mathrm{f} / 1$ \\
\hline Vicinity of the dismantling area & Mar. 9-16, 1995 & $0.8-7.7 \mathrm{f} / 1$ & $2.6 \mathrm{f} / 1$ & $3.0 \mathrm{f} / 1$ \\
\hline Vicinity of the dismantling area & Apr. 24-28, 1995 & $0.9-9.5 \mathrm{f} / 1$ & $5.4 \mathrm{f} / 1$ & $3.8 \mathrm{f} / 1$ \\
\hline General level around the main road & 一 & $\mathrm{ND}-3.7 \mathrm{f} / 1$ & - & $0.43 \mathrm{f} / 1$ \\
\hline General level in the housing area & - & $\mathrm{ND}-1.2 \mathrm{f} / 1$ & - & $0.14 \mathrm{f} / 1$ \\
\hline General level in the commercial and industrial area & - & $\mathrm{ND}-1.3 \mathrm{f} / 1$ & - & $0.17 \mathrm{f} / 1$ \\
\hline
\end{tabular}

Data were obtained by the Environmental Agency of Japan. 


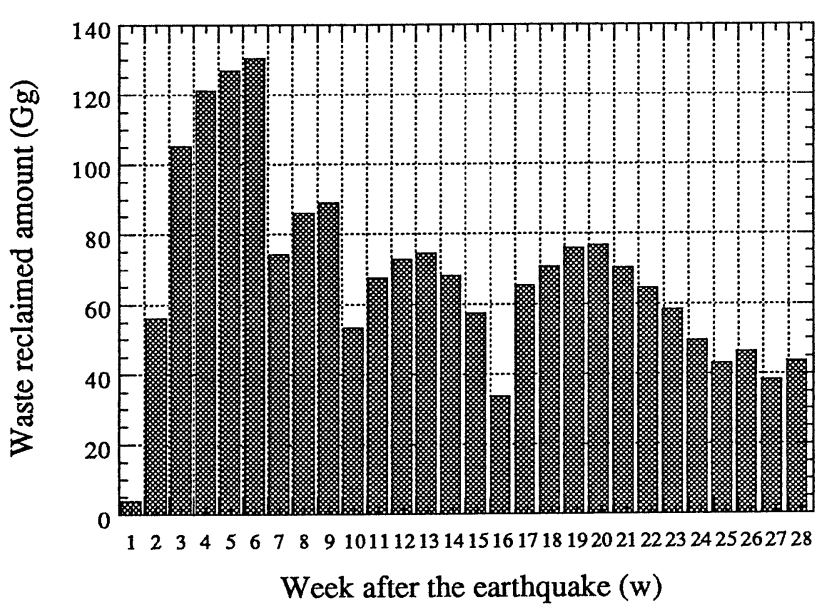

Fig. 4. Amount of disaster waste reclaimed at the Fusehata disposal site

tional cause of traffic congestion. As indicated in Fig. 4, the trucks loaded the debris gathered from collapsed individual house to the Fusehata disposal site located in an inland area of Kobe city, which caused severe traffic congestion on the access road for the first several weeks after the earthquake. In addition because there was no coordination between the capacity of the access road and the upper limit of daily capacity of the trucks at the disposal site.

\section{Temporary Storage and Intermediate Treatment}

Because of insufficient on-site separation of waste, waste material was not acceptable at the "Phoenix Center" disposal site until such waste went through a separation and size reduction process. Stockpile of mixed waste therefore increased at open spaces designated as temporary storage, as shown in Photos. 1, 3 and 4 . In Nishinomiya city, for example, waste was separated into three piles: incombustible waste, wooden waste and residential waste. As a means to reduce the amount of waste and also for sanitary reasons, illegal incineration at temporary stockyard continued only to the end of April when the Hyogo prefectural government banned it com-

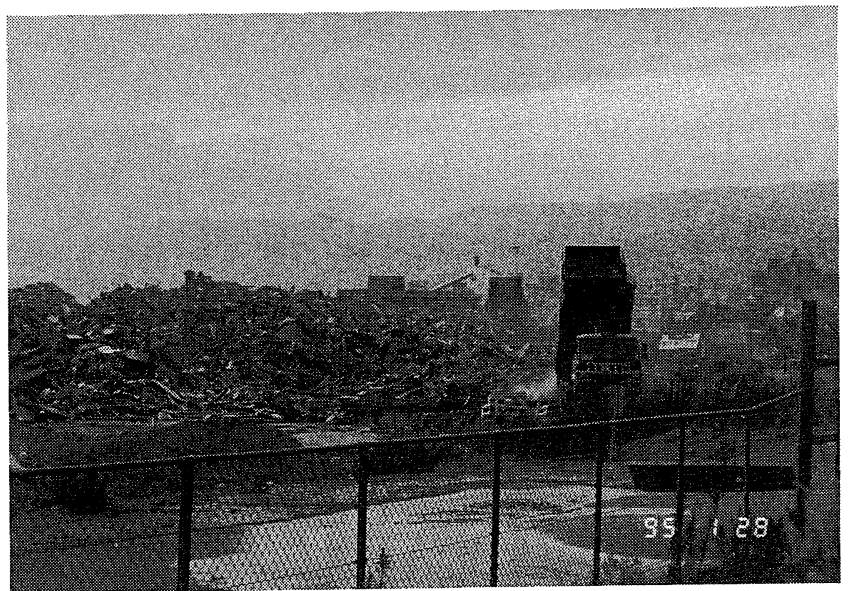

Photo. 3. Temporary stockpile location in Nishinomiya city
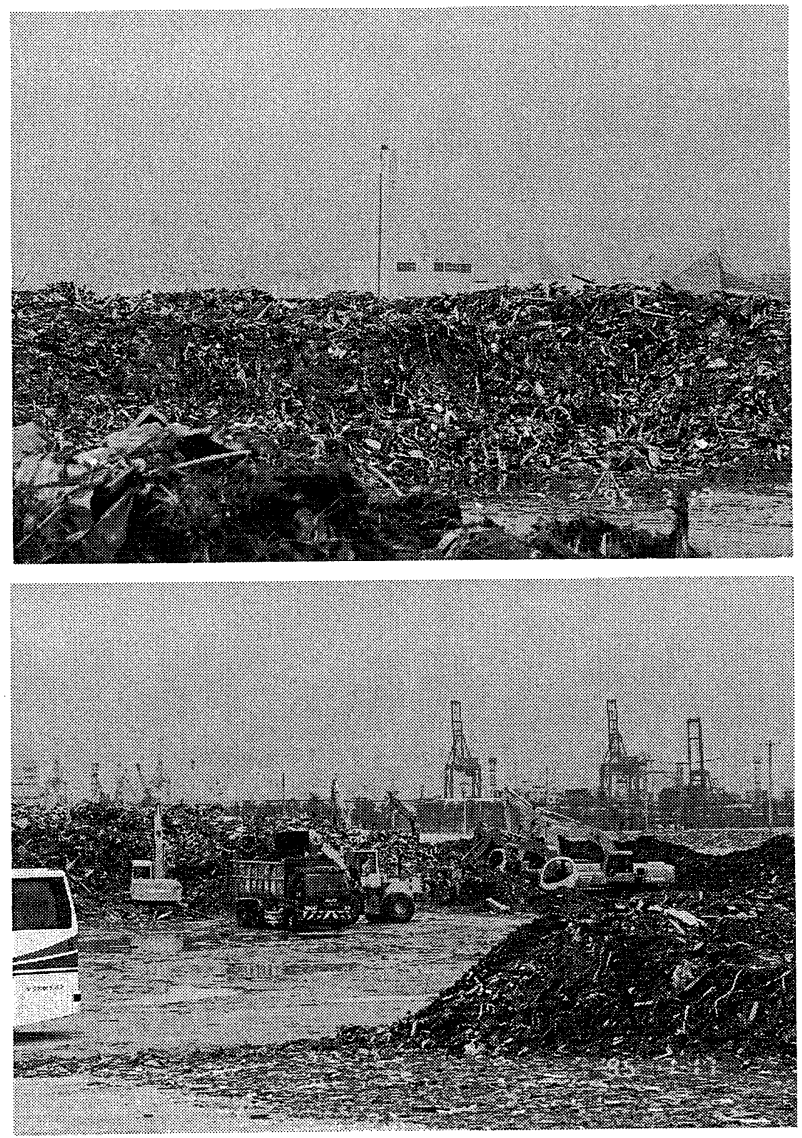

Photo. 4. Temporary stockpile in Kobe city

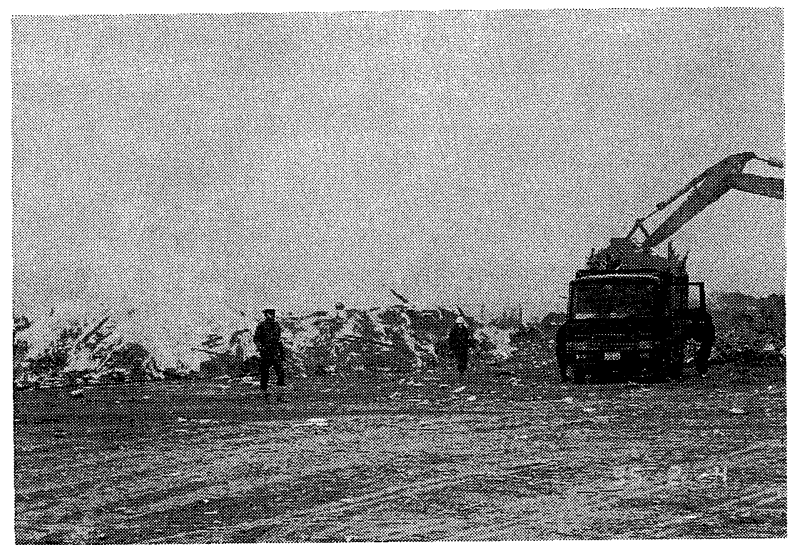

Photo. 5. Open incineration

pletely, as shown in Photo. 5. In other cases, demolition contractors dumped and incinerated the debris illegally. Air pollution from ashes and odor became issues for the neighbors so that the Environmental Agency in collaboration with Hyogo prefectural government conducted a field investigation. As Table 6 shows a negligible deterioration in air quality was found in general except for several spots where dioxin was detected near the illegal incineration sites. Accordingly, illegal incineration caused more psychological dissatisfaction for the citizens living around the temporary storage locations. 
Table 6. Results of measurement of air pollution due to open burning

\begin{tabular}{|c|c|c|c|c|}
\hline Substance & Min.-Max. Value & Medium value & General level & $\begin{array}{c}\text { Environmental } \\
\text { standard }\end{array}$ \\
\hline $\begin{array}{l}\mathrm{HCl} \\
\text { Formaldehyde } \\
\text { Acetaldehyde } \\
\text { Acrolein } \\
\text { Dioxin } \\
\text { Benzo[a]pyrene } \\
\text { PCB } \\
\text { As } \\
\text { Phosgen } \\
\mathrm{HCN} \\
\mathrm{CO} \\
\mathrm{CO}_{2}\end{array}$ & $\begin{array}{l}\text { ND-4 ppb } \\
\text { ND-10 } \mu \mathrm{g} / \mathrm{m}^{3} \\
3-11 \mu \mathrm{g} / \mathrm{m}^{3} \\
\text { ND } \\
0.0000-0.0023 \mathrm{ng} / \mathrm{m}^{3} \\
\text { ND-2.7 } \mathrm{ng} / \mathrm{m}^{3} \\
\text { ND } \\
\text { ND } \\
\text { ND } \\
\text { ND } \\
\text { ND-0.9 ppm } \\
12-68 \mathrm{ppb}\end{array}$ & $\begin{array}{l}\mathrm{ND} \\
\mathrm{ND} \\
7 \mu \mathrm{g} / \mathrm{m}^{3} \\
\mathrm{ND} \\
0.0001 \mathrm{ng} / \mathrm{m}^{3} \\
1.0 \mathrm{ng} / \mathrm{m}^{3} \\
\mathrm{ND} \\
\mathrm{ND} \\
\mathrm{ND} \\
\mathrm{ND} \\
0.3 \mathrm{ppm} \\
23 \mathrm{ppb}\end{array}$ & $\begin{array}{l}-32 \mu \mathrm{g} / \mathrm{m}^{3} \\
-22 \mu \mathrm{g} / \mathrm{m}^{3} \\
0.00262 \mathrm{ng} / \mathrm{m}^{3} \\
-3.5 \mathrm{ng} / \mathrm{m}^{3}\end{array}$ & $\begin{array}{l}10 \mathrm{ppm} \\
40-60 \mathrm{ppb}\end{array}$ \\
\hline
\end{tabular}

Data were obtained by the Environmental Agency of Japan.

Table 7. Capacity of disposal site

\begin{tabular}{l|l|r}
\hline & \multicolumn{1}{|c|}{ Location } & Capacity $\left(\mathrm{m}^{3}\right)$ \\
\hline \multirow{2}{*}{$\begin{array}{l}\text { New } \\
\text { coastal } \\
\text { reclamation } \\
\text { site }\end{array}$} & $\begin{array}{l}\text { Port Island (Kobe city) } \\
\text { Maya Wharf (Kobe city) }\end{array}$ & 700000 \\
& South Rokko Island (Kobe city) & 2200000 \\
& Sinminato Higashi (Kobe city) & 2400000 \\
\cline { 2 - 3 } & Naruo and others (Hanshin) & 900000 \\
\hline \multirow{4}{*}{$\begin{array}{l}\text { Existing } \\
\text { site }\end{array}$} & Subtotal & 7400000 \\
\hline & Amagasaki-oki (Phoenix) & 4000000 \\
& Izumiohtsu-oki (Phoenix) & 11000000 \\
\cline { 2 - 3 } & Fusehata (Kobe city) & 8000000 \\
& Ougo (Kobe city) & 7000000 \\
\cline { 2 - 3 } & Port of Osaka (Osaka city) & 2000000 \\
\cline { 2 - 3 } & Sakai-Senboku (Osaka Pref.) & 400000 \\
\cline { 2 - 3 } & Inaho (Hyogo Pref.) & 1200000 \\
\hline & Total & 41000000 \\
\hline
\end{tabular}

Data is based on the disaster waste management plan of Hyogo prefeciral government.

\section{Disposal and Recycling of Disaster Waste}

Table 7 shows the recycling and disposal capacity of disaster waste as reported by the Hyogo prefectural government. The foal was that concrete and metal scrap would be reserved for reuse and the remaining $40 \%$ of waste would be disposed of in the Phoenix Center after proper treatment such as incineration. Approximately $10,000 \mathrm{Gg}$ of concrete will be reused in the new coastal reclamation plan in Kobe Harbor, as shown in Fig. 5, which was a post-hoc plan to obtain ample reclamation space for recycling.

\section{EMERGENCY MANAGEMENT PERSPECTIVES FOR DEBRIS CLEARANCE}

It is important to treat the debris clearance issue as one of the most important emergency management issues. Since the debris clearance issue adopted a construction waste processing scheme as the model for its operation, civil engineers in this field tended to regard debris clearance as a matter of securing ample space for temporary stockpiling and disposal. The solution for them might be the "Phoenix Center" in the Kansai region. From the geotechnical perspective, however it would be of great concern to have an incredible amount of material less qualified for reclamation. The future of the debris reclaimed land might be jeopardized unless proper precaution has been taken to consider the geotechnical engineering aspects to control the quality of incoming reclaimed material. For this purpose, information about the entire debris clearance management program and the coordination based on such information are indispensable.

\section{GIS Information for Debris Clearance Management}

In Nagata ward of Kobe city a geographic information system (GIS) has been adopted to help the application process for disaster victims by showing the houses targeted for demolition and relevant information on monitor screen (Kameda et al., 1995). This system also allows for the city officers by maintaining an unified database for debris clearance to keep track of their operations based on the application form, the identification of efficient demolition operation procedure, the monitoring against illegal cartel formation by demolition contractors, and the execution of contract forms. As a result, Nagata ward finished all of their contracts with demolition contractors by the end of April 1995, whereas other wards using a regular system were still in the middle of contracting. This is an example of how information processing is important in debris clearance.

\section{Multiple Criteria for Evaluating the Debris Clearance Operations}

Another example of the importance of the emergency management perspective is the social constraint set by the national government as to the date of the completion of debris clearance. In return to the subsidiary, national government requested that the local municipalities finish 


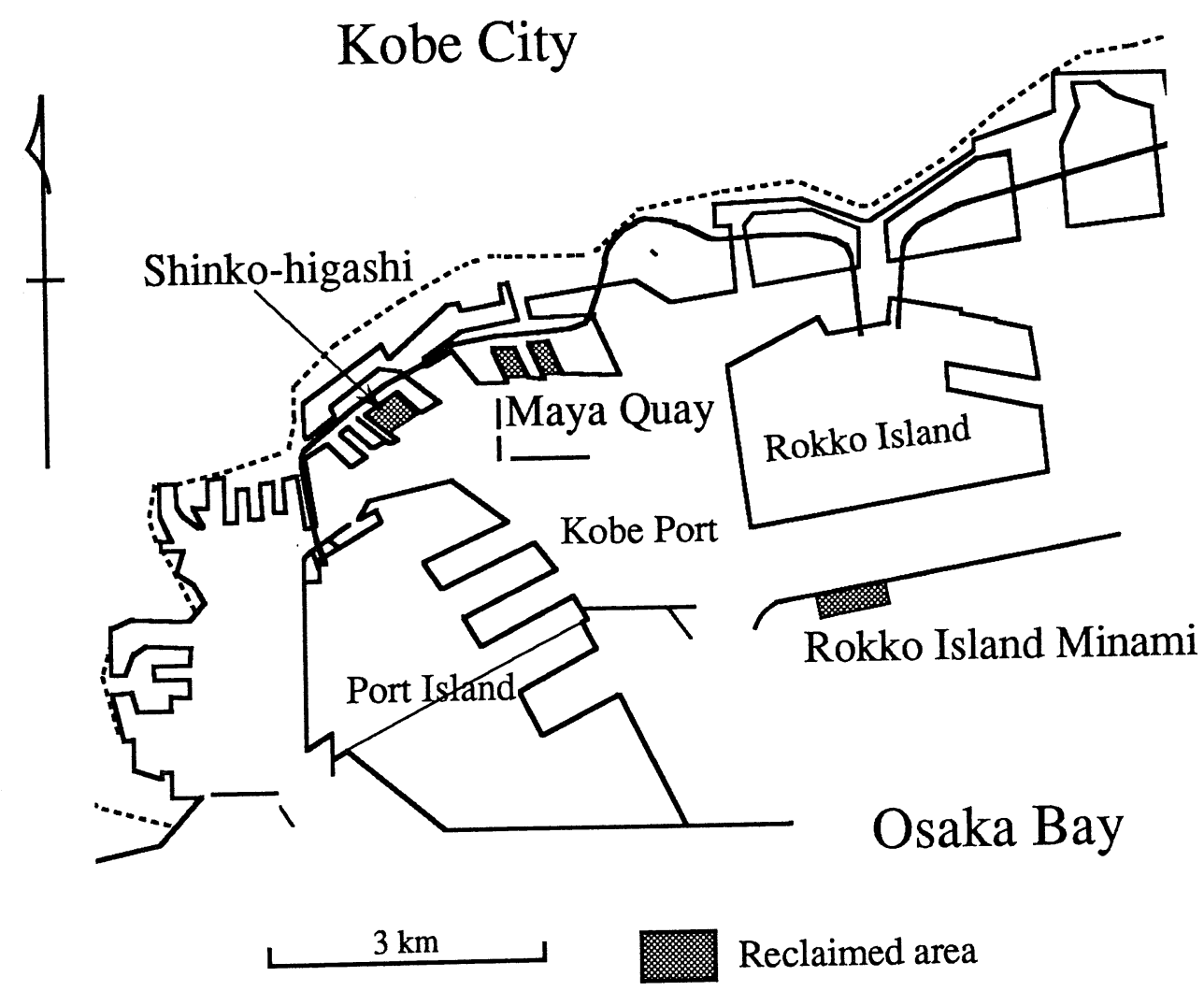

Fig. 5. Reclamation plan for concrete debris in Kobe Harbor

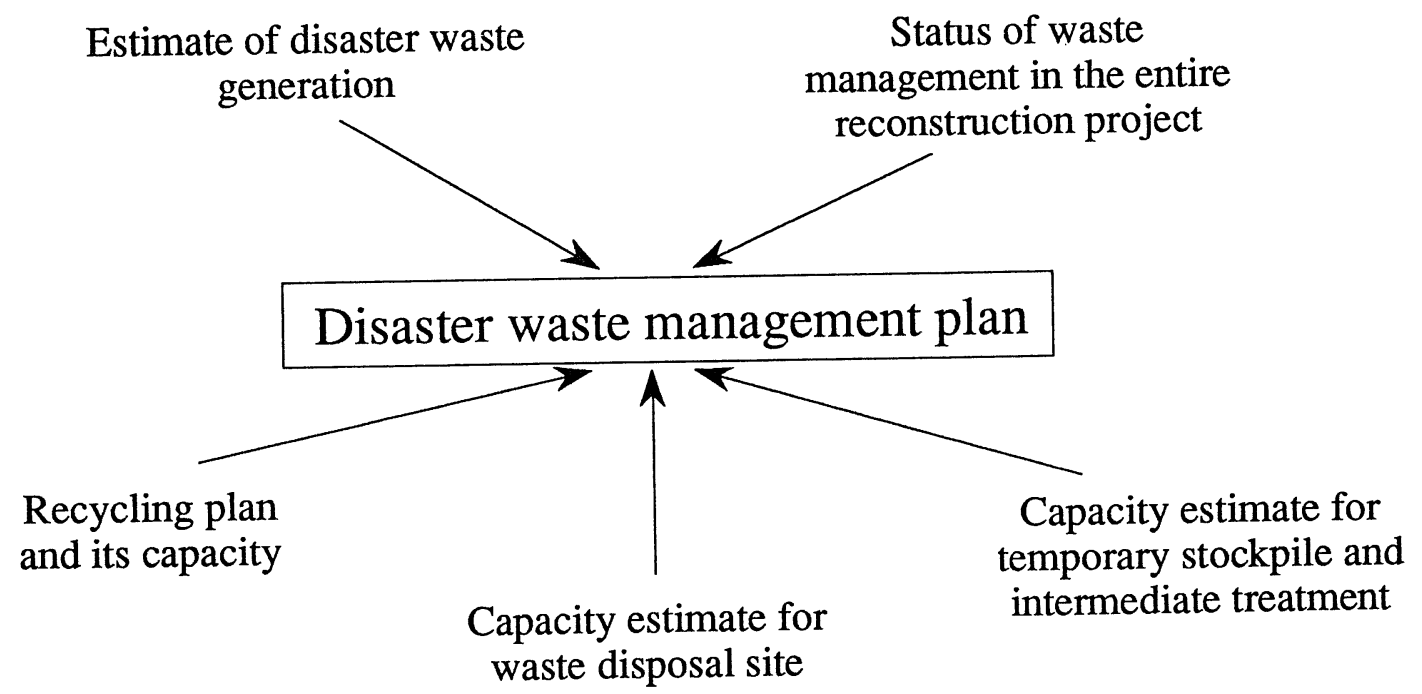

Fig. 6. Flow chart for disaster waste management plan

the demolition of the collapsed buildings by March 1996, and the complete operation by March 1997. Even though the technical background for these assessments may not be clear, these assessments will function as the standards for evaluating the debris clearance. In some cases, engineers may have to come up with new technologies and devices, or some new ways of handling business to meet this deadline. Even though $97.5 \%$ of the expenses needed for debris clearance of private buildings was covered, it is still another important criterion of managing business to minimize the operation cost. In addition, a total of $20,000 \mathrm{Gg}$ of the debris may urges the engineers to halt all the regulations as to the processing of industrial wastes, but the respect for the present waste processing scheme is important to secure continuity of waste disposal. The basis for reasonable future operations in terms of environmental protection and in terms of quality of material reclaimed at the least controlled disposal 
site would be lost. Engineers facing the debris clearance must take into account all the criteria proposed, before they decide with little time allowance. As shown in Fig. 6 , therefore $t$ is definitely an emergency management issue which requires coordination among the relevant sectors.

\section{CONCLUSIONS}

The 1995 Hyogoken-Nambu earthquake which occurred on January 17, 1995 resulted in devastating damage to the highly developed, urbanized Kansai region, and created a total of $20,000 \mathrm{Gg}$ of debris. Debris clearance within two years became an urgent and difficult emergency management issue for the disaster managers in Kobe city and Hyogo prefecture.

1) Providing ample space for temporary storage and disposal is not sufficient to make the debris clearance efficient.

) The lack of coordination for the debris management phases of demolition, transportation, temporary storage and intermediate treatment, and final disposal resulted in many environmental and psychological problems in the impacted area.

3) The control of quality of incoming reclaimed material to the disposal site must be maintained in order not to jeopardize the waste management scheme in Japan even under emergency situations.

4) In order to evaluate the debris clearance management, there are many criteria related to the coordination of the entire management process in a single coherent system.

5) Information about the debris clearance operation is the key element for such coordination.

\section{ACKNOWLEDGMENTS}

We gratefully acknowledge all the members of the "disaster waste"' working group of the Research Committee for the Great Hanshin-Awaji Earthquake Disaster, sponsored by the Japanese Geotechnical Society, for their active participation for the discussions for this paper. We also thank Professors Toshihisa Adachi and Masashi Kamon from Kyoto University for their encouragement for our research project. Finally, we would like to express our deep appreciation for the cooperation given us by the Kobe municipal government, the Hyogo prefectural government, the "Phoenix Center," and the Itami municipal government.

\section{REFERENCES}

1) Irie, T. and Mori, K. (1995): "Disaster waste disposal in Phoenix Center due to the 1995 Hyogoken-Nambu earthquake," Environ. Sanit. Eng. Res., Vol. 9, No. 3, pp. 150-152 (in Japanese).

2) Japanese Geotechnical Society (1996): "Selected photographs on the damage caused by the 1995 Hyogoken-Nambu earthquake," Soils and Foundations, Special Issue on the 1995 Hyogoken-Nambu Earthquake.

3) Kameda, H., Kakumoto, S., Iwai, S., Hayashi, H. and Usui, T. (1995): "DiMSIS: A geographic information system for disaster information management of the Hyogoken-nambu earthquake," Jour. Natural Disaster Science, Vol. 16, No. 2, pp. 89-94.

4) Kamon, M. (1994): “Geotechnics of waste management," Proc. 1st National Symposium Environmental Geotechnology, JSSMFE, pp. 11-20 (in Japanese).

5) Kasuya, A. and Iwasa, K. (1995): "Practice and system of disaster waste management," Environ. Sanit. Eng. Res., Vol. 9, No. 3, pp. 144-149 (in Japanese).

6) Kobayashi, E. (1995): “Countermeasures for air pollution after the Great Hanshin-Awaji Earthquake Disaster," Environ. Sanit. Eng. Res., Vol. 9, No. 3, pp. 121-124 (in Japanese). 